\title{
Pelagic habitat of seabirds in the eastern tropical Pacific: effects of foraging ecology on habitat selection
}

\author{
L. Ignacio Vilchis ${ }^{1,2, *}$, Lisa T. Ballance ${ }^{2}$, Paul C. Fiedler ${ }^{2}$ \\ ${ }^{1}$ Integrative Oceanography Division, Scripps Institution of Oceanography, 9500 Gilman Drive, La Jolla, \\ California 92093-0227, USA \\ ${ }^{2}$ Ecosystem Studies Program, Southwest Fisheries Science Center, NOAA Fisheries, 8604 La Jolla Shores Drive, La Jolla, \\ California 92037, USA
}

\begin{abstract}
A central tenet of ecology is the quantification of species-habitat relationships in order to explain spatial variability in the distribution and abundance patterns of animals. We quantified habitat preferences for 6 tropical seabird species representing a phylogenetically and ecologically diverse group within the eastern tropical Pacific (ETP). Seabird censuses were conducted aboard NOAA research vessels from August to November of 1989 and 1990 using 300 m strip transect methods. Simultaneously with the seabird censuses and from the same ships, oceanic habitat was quantified by measuring sea surface temperature, salinity, and chlorophyll, as well as thermocline depth and strength. We quantified seabird habitat using generalized additive models fitted with forward and backward selection algorithms based on minimizing the Akaike information criterion (AIC). In general, seabird habitat models performed well in explaining spatial variability in abundance, reducing the null deviance to ranges between 42.8 and $73.5 \%$, and predicting seabird density patterns with an accuracy ranging from 56.6 to $80.5 \%$. Relative abundance of the species modeled affected the outcome: the higher the abundance, the more robust the fit. Seabirds feeding on fishes and squids associated with habitats characterized by deep $(>100 \mathrm{~m})$ and strong $\left(>2{ }^{\circ} \mathrm{C} 10 \mathrm{~m}^{-1}\right)$ thermoclines, while planktivorous species preferred habitat characterized by shallower thermoclines with cooler surface temperatures $\left(<25^{\circ} \mathrm{C}\right)$ and a less stratified water column. Thus, seabirds in different feeding guilds have clear and distinct habitat preferences within the ETP. We propose thermocline topography as a key variable in predicting distribution and abundance of seabirds in this area, probably due to its influence on the availability of seabird prey.
\end{abstract}

KEY WORDS: Eastern tropical Pacific - Habitat relationships - Seabirds · Foraging ecology • Thermocline depth · Generalized additive models

Resale or republication not permitted without written consent of the publisher

\section{INTRODUCTION}

Differentiation of habitat preferences of similar species is one of the principle interactions allowing species to coexist. Hence, a fundamental goal of ecology is to identify the mechanisms linking species with their habitat. Most habitat selection studies are based on terrestrial systems rather than marine, in part because of the logistic constraints of sampling large and inaccessible areas of the ocean. As a result, ecological tenets of habitat selection are largely based on terres- trial studies and, to a lesser extent, in marine systems on intertidal and benthic research (Rosenzweig 1981). Less is known of how open ocean ecosystems emulate terrestrial based ecological theory. This is particularly relevant to the tropics, which cover by far the largest area of the world's oceans.

In oceanic systems, physical processes determine environmental structure and, hence, oceanic habitat (McGowan 1986). Examples of these processes are divergence and convergence zones between surface currents, cyclonic eddies, and upwelling zones, all of 
which create oceanic habitat. In the tropical Pacific and east of $120^{\circ}$, oceanic habitat is influenced by the proximity of the American continents and 2 thermocline ridges which shoal from west to east across the Pacific. The North Equatorial Counter Current (NECC), for instance, is deflected northward by Central America. Additionally, wind jets blowing through mountain gaps in Central America create regionspecific upwelling patterns and the Costa Rica Dome, a quasi-permanent cyclonic eddy located off shore Nicaragua and Costa Rica (Fig. 1). Because of the shoaling thermocline ridges, cool and nutrient-rich water is closer to the sea surface in the eastern tropical Pacific (ETP). Equatorial upwelling and the Costa Rica Dome can then create unique, highly productive oceanic regions, making the oceanic habitat of the ETP more heterogeneous and productive than other tropical oceans (Kessler 2002, Fiedler 2003, Ballesteros \& Coen 2004).

Seabird oceanic habitat is commonly quantified by correlating spatial distributions of sightings with environmental variables. For example, studies have quantified seabird habitat using physical parameters describing water masses, e.g. temperature and salinity (King 1974, Pocklington 1979, Ainley \& Boekelheide 1983, Wahl et al. 1989). Physical proxies for seabird distribution and abundance should include more than just temperature and salinity, since seabird habitat selection is most likely a function of prey abundance and/or availability and comprised of a mosaic of environmental variables.

Seabird habitat has been quantified using multiple parameters with multivariate techniques, such as classification tree methodology and canonical correspondence analysis (Ribic \& Ainley 1997, Ribic et al. 1997a). The non-linear nature of ocean dynamics, however, can limit modeling techniques with parametric constraints. Recently, non-linear habitat modeling techniques utilizing generalized additive models (Hastie \& Tibshirani 1999) have been applied to marine vertebrate ecology with relative success (Swartzman et al. 1995, Hedley et al. 1999, Forney 2000, Stoner et al. 2001, Clarke et al. 2003, Spear \& Ainley 2005). Generalized additive models (GAMs) extend classical regression by exchanging linear regression coefficients with non-parametric smoothing functions. Additionally, they allow the probability distribution of the response variable, as well as the link between the predictors and the probability distribution, to be more general. Animal counts generally show nonGaussian distributions and ocean habitat tends to have multi-dimensional and non-linear dynamics, GAMs can therefore, maximize the quality of description, inference, and prediction of seabird habitat.

The purpose of this study was to test known habitat preferences of oceanic tropical seabirds by quantifying the oceanographic correlates for the abundance patterns of 6 species of seabirds in the ETP using generalized additive models. We wished to see if predicted habitat coincides with habitat observed and, if so, how does foraging ecology influence habitat selection.

\section{MATERIALS AND METHODS}

Study area. Our study area is in the ETP between latitudes $30^{\circ} \mathrm{N}$ and $20^{\circ} \mathrm{S}$ and from the west coast of the American continent to $160^{\circ} \mathrm{W}$ longitude. It is a large area, encompassing just over 20 million $\mathrm{km}^{2}$ of ocean surface. Surface oceanography is dominated by 3 major currents: the North and South Equatorial Currents (NEC and SEC, respectively) and the NECC, by 4 water masses, and a basinwide west-to-east shoaling thermocline (Fig. 1). Wyrtki (1966) defined 3 surface water masses in the ETP according to their temperature and salinity and climatic interactions at local or remote points of origin: (1) tropical surface water $\left(25-28^{\circ} \mathrm{C}\right.$, $33-34 \mathrm{psu}),(2)$ equatorial surface water $\left(20-28^{\circ} \mathrm{C}\right.$, $33-35 \mathrm{psu})$, and (3) subtropical surface water $\left(19-28^{\circ} \mathrm{C}\right.$, $35-36.5 \mathrm{psu})$. A fourth water mass, upwelling-modified surface water, lies in certain areas in the eastern boundary of the tropical surface water mass along the Central American Bight within the Gulfs of Tehuantepec, Papagayo and Panama, where intense mountaingap wind jets create bands of downwelling and upwelling wind stress curl extending at least $500 \mathrm{~km}$ into the Pacific (Au \& Perryman 1985, Kessler 2002, Ballesteros \& Coen 2004). In these areas, wind-forced upwelling and the quasi-permanent cyclonic Costa Rica Dome create patches of $\operatorname{cool}\left(<25^{\circ} \mathrm{C}\right)$ nutrient rich water within the less productive and warmer tropical surface water mass.

Data collection. We collected data from 2 National Oceanic and Atmospheric Administration (NOAA) research vessels, the 'David Starr Jordan' and 'McArthur', which were both deployed to the ETP from 28 July to 9 December in both 1989 and 1990. The effort totaled $386 \mathrm{~d}$ at sea, during which $18848 \mathrm{~km}^{2}$ of ocean surface were surveyed for seabirds (Table 1, Fig. 1). Cruise track-lines (Fig. 1) were distributed randomly within

Table 1. Seabird survey effort in the eastern tropical Pacific Ocean. (See Lierhiemer et al. 1990a,b and Philbrick et al. 1991a,b for sampling and cruise details)

\begin{tabular}{|lccc|}
\hline Year & $\begin{array}{c}\text { Days } \\
\text { at sea }\end{array}$ & $\begin{array}{c}\text { Time surveyed } \\
(\mathrm{h})\end{array}$ & $\begin{array}{c}\text { Area surveyed } \\
\left(\mathrm{km}^{2}\right)\end{array}$ \\
\hline 1989 & 191 & 1661 & 9022 \\
1990 & 196 & 1724 & 9826 \\
1989,1990 & 387 & 3385 & 18848 \\
\hline
\end{tabular}



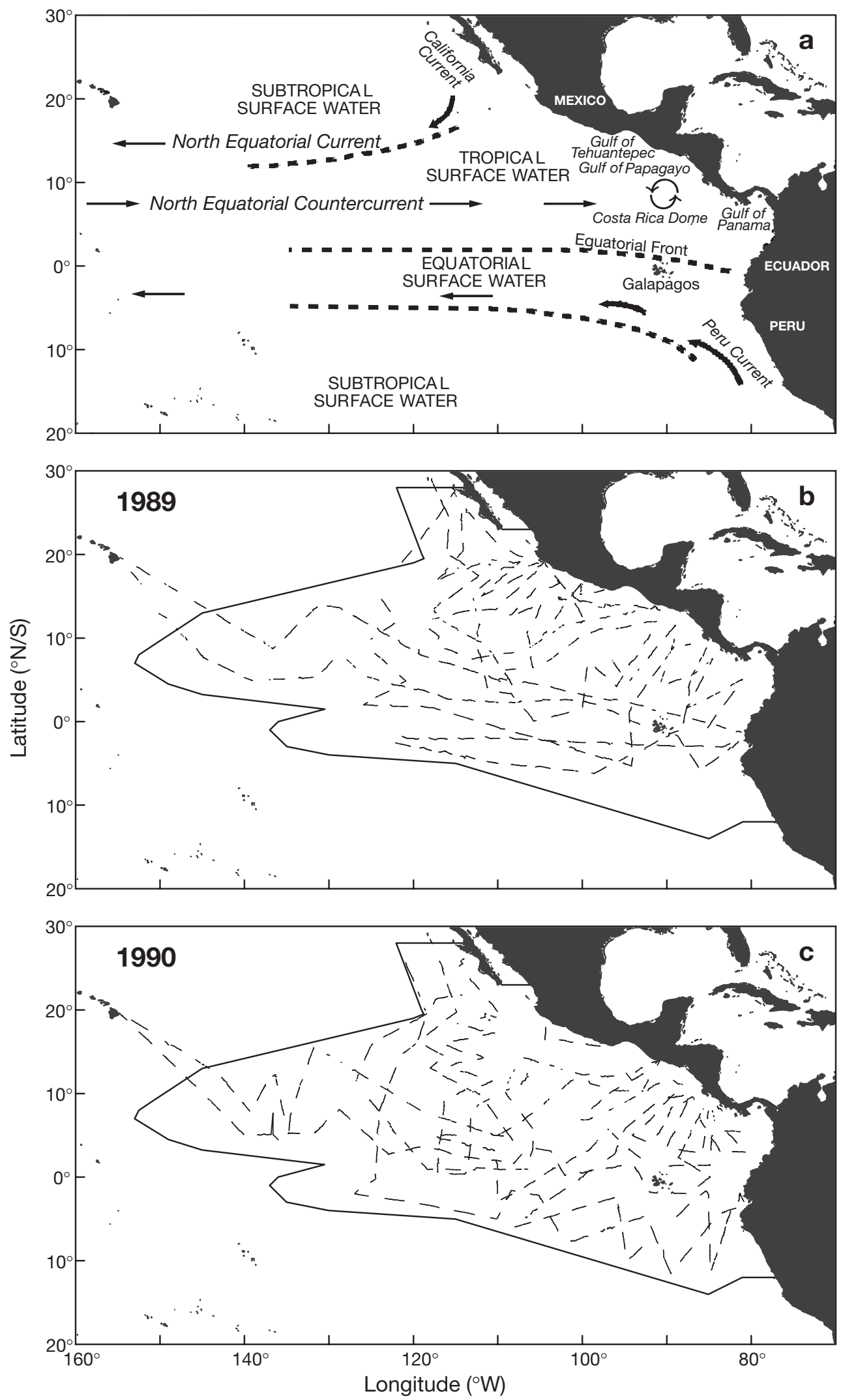

Fig. 1. (a) Surface currents and water masses in eastern tropical Pacific Ocean (adapted from Wyrtki 1966, 1967, Fiedler 1992); $(\mathrm{b}, \mathrm{c})$ track-lines of seabird surveys and outline of boundary of study area 
the study area, which was designed to sample the known range of spotted (Stenella attenuata) and spinner (S. longirostris) dolphins, species which have been incidentally affected by the yellowfin tuna (Thunnus albacares) purse-seine fishery (see Gerrodette \& Wade 1991, Wade \& Gerrodette 1992). Seabird and oceanographic data were collected concurrently with dolphin surveys as part of an ecosystem studies program.

Seabird census data were collected using standard 300 m strip transect methods (Tasker et al. 1984). While the ship cruised at 10 knots on its predetermined trackline (Fig. 1), a single observer stationed on the flying bridge recorded all seabirds that entered a $90^{\circ}$ arc with a $300 \mathrm{~m}$ radius, spanning from the bow to the beam of the ship on the side with the best visibility conditions. Hand-held binoculars were used to aid in species identification. Data were collected during all daylight hours, weather permitting (generally up to Beaufort 6). Age, sex, associations (with other seabirds, cetaceans, fish, turtles or floating objects) and behavior (sitting, flying, feeding or ship-following) were also recorded. Ship-following birds were recorded a single time only each day, when first encountered.

Sea surface temperature and salinity were recorded continuously with a thermosalinograph and discrete surface chlorophyll samples were taken every $3 \mathrm{~h}$. Thermal structure of the water column was sampled with expendable bathythermographs deployed 4 to 6 times $\mathrm{d}^{-1}$ (every 55 to $90 \mathrm{~km}$ ) and with conductivity-temperature-depth instruments deployed twice daily, $1 \mathrm{~h}$ before sunrise and $1 \mathrm{~h}$ after sunset. A global positioning system provided continuous geographical position.

Data analyses. We investigated oceanographic correlates of distribution and abundance for 6 species of seabirds representing a diverse group with respect to phylogeny and ecology (e.g. diet and foraging methods), as well as being commonly present in relatively high numbers in the ETP. Our group comprised 4 Procellariiformes (Juan Fernandez petrel Petrodroma externa, wedge-tailed shearwater Puffinus pacificus, Leach's storm petrel Oceanodroma leucorhoa, and wedge-rumped storm petrel O. tethys) and 2 Pelecaniformes (red-footed booby Sula sula and red-tailed tropicbird Phaethon rubricauda). Of these species, 4 feed on nektonic fishes and squids (Juan Fernandez petrel, wedge-tailed shearwater, red-footed booby and red-tailed tropicbird: Harrison et al. 1985), and 2 species feed on micronekton and plankton (Leach's and wedge-rumped storm petrels: Pitman \& Ballance 1990); 3 species are dependent upon subsurface predatory fishes and cetaceans for feeding opportunities (Juan Fernandez petrel, wedge-tailed shearwater and red-footed booby), 2 feed at physical features (Leach's and wedge-rumped storm petrel), and 1 species feeds only on scattered prey items (red-tailed tropicbird) (Huntington et al. 1996, Ballance \& Pitman 1999, Spear et al. 2001).

We used a single survey day as our sampling unit. Changes in environmental properties in the open ocean tend to occur on a scale of hundreds to thousands of kilometers (Owen 1981). Variation of physical properties in the waters traversed in the course of $1 \mathrm{~d}$ (150 to $200 \mathrm{~km}$ ) averaged 1 order of magnitude less than the variation throughout the entire study area (Fiedler 1992). Other studies in the ETP have used the 150 to $200 \mathrm{~km}$ spatial scale to investigate habitat preferences of pelagic seabirds and cetaceans with successful results (Reilly \& Fiedler 1994, Ballance et al. 1997). We therefore believe that a single survey day represents an appropriate spatial scale for our analysis goals. For each survey day, we calculated the total area surveyed, mean sea surface temperature (SST), and salinity (SSS), mean sea surface chlorophyll (Chl), mean depth $(z)$ of the $20^{\circ} \mathrm{C}$ isotherm $\left(z_{20}\right)$ which in the ETP is essentially equivalent to the thermocline depth (Fiedler 1992), and the mean vertical temperature gradient between the 20 and $15^{\circ} \mathrm{C}$ isotherms $\left(z_{\mathrm{DIF}}\right)$; as well as the total number of seabirds recorded for each of the 6 species studied.

Model development and selection. GAMs extend generalized linear models in the same manner that additive models extend linear regression models (Hastie \& Tibshirani 1999). We applied this regression tool to better understand the non-Gaussian and nonlinear correlates of seabird habitat, since many aspects of open ocean ecosystems have these characteristics. A GAM is comprised of a response variable, an additive predictor, and a link function which links the 2 components. In a model with $p$ explanatory variables it has the following form:

$$
g(\mu)=\alpha+\sum_{j=1}^{p} f_{j}\left(x_{j}\right)
$$

where $\mu$ is the mean of the response variable, $\alpha$ is a constant term, $f_{j}$ are the nonparametric smoothing functions of the explanatory variables, $x_{j}$, and $g$ is the link function. In this study, response variables were the daily total counts of each seabird species studied, whereas the explanatory variables were the daily mean values of the oceanographic parameters used to describe habitat. Data involving counts generally have Poisson distributions as there is a small probability of the occurrence of a single event. Pelagic seabirds often show clustered distributions; in these cases the Poisson distribution is not appropriate as an error structure because of over-dispersion: the dispersion of the data is greater than that predicted by the Poisson model (McCullagh \& Nelder 1989, Hedley et al. 1999). This is remedied by specifying an error structure with a variance function proportional, rather than equal, to the mean (Hedley et al. 1999). Additionally, the canonical parameter of the Poisson distribution 
to the additive predictor is logarithmic. Therefore, a GAM with a logarithmic link function and overdispersed Poisson error distribution was fitted to the count data of each seabird species.

Habitat parameters that were considered for inclusion in the model as cubic smoothing splines with 2, 3 or 4 degrees of freedom (df) or as linear terms were SST, SSS, log-transformed Chl, $z_{20}$ and $z_{\text {DIF }}$. Cubic smoothing splines fit data using piecewise cubic polynomials; these were selected as the smoothing mechanism because their performance is superior to that of other smoothing algorithms (Hastie \& Tibshirani 1999, Fewster et al. 2000). The extent to which these smoothing splines fit the data is governed by the df given to the smoothing algorithm. For instance, a linear function corresponds to a fit with $1 \mathrm{df}$. As the df are increased, the smoothing function increases in flexibility and is allowed to track the data in a more realistic fashion, up to a maximum where the df equals the number of data points. Choosing the appropriate degree of smoothing is an important part of the modeling process, and this choice depends largely on the objectives of the analysis. For this study, we set the scope of the smoothing terms at a maximum of 4 in order to be able to see non-linear trends but also to reduce the chances of over-fitting the data (which can result in unrealistic patterns and sampling artifacts: Fewster et al. 2000, Forney 2000). Other studies modeling spatial variation in densities of organisms have used $4 \mathrm{df}$ as a maximum for the same reasons (Borchers et al. 1997, Forney 2000, Stoner et al. 2001).

The area surveyed per day was not uniform throughout the study, and using this area to calculate seabird densities would bias the model selection process. Instead, the area surveyed on each day (i) was included as an offset variable $\left(a_{i}\right)$ to correct for this sampling imbalance (Chambers \& Hastie 1992). The form of the model was therefore:

$$
g(\mu)=\left[\log \left(a_{i}\right)+\alpha+\sum_{j=1}^{p} f_{j}\left(x_{j}\right)\right]
$$

Final models were selected with automated forward and backward stepwise selection algorithms based on minimizing the Akaike information criterion, AIC (Akaike 1973), which also adjusts for overdispersion in the model selection. In this process, an AIC statistic is calculated for the current model, as well as for all reduced or augmented models, using covariates within the set smoothing scope; terms are subsequently added or dropped to minimize the AIC statistic.

Model validation. Using data from 1989, we fitted habitat models for each species via the stepwise selection procedure described above. Model goodness-of-fit was gauged by calculating the percent reduction in deviance:

$$
\left(\frac{\text { null deviance }- \text { residual deviance }}{\text { null deviance }}\right) \times 100
$$

In generalized linear models the deviance, a log likelihood measure of the discrepancy between the data and the model, plays the role of the residual sum of squares in classical regression, and is used to assess goodness-of-fit (McCullagh \& Nelder 1989). For generalized additive models, the distribution theory for the deviance has not been completely developed, but reduction in deviance can still be used as an indicator of model utility (Hastie \& Tibshirani 1999). Deviance measures how well the model fits the data in the sense that, if the model fitted the data perfectly, the deviance would be exactly zero. The change in deviance then measures how much of an improvement the model contributes compared to using simply the overall average bird density (i.e. without considering any covariates). The larger the change in deviance, or the greater the percent reduction in deviance attributable to the model, the better the model explains variability in the data.

We evaluated the variance of the goodness-of-fit estimates of each seabird habitat model with a nonparametric bootstrap, which selected 500 bootstrap samples at random with replacement from the 1989 survey year data. Bootstrap samples were fit with the AIC-based stepwise selection algorithm, including explanatory variables as smoothing splines with 0 to $4 \mathrm{df}$. The bootstrap estimate of standard error (Efron \& Tibshirani 1986) and coefficient of variation were then calculated from the 500 bootstrap samples corresponding to each seabird species.

Additional model validation was achieved by comparing observed species distributions in 1990 with those predicted for 1990 using the model constructed with 1989 data. We used a 4-way classification comparison with 4 possible outcomes: (1) model predicted birds present and birds were also observed; (2) model predicted birds present but no birds were observed; (3) model predicted no birds present and birds were observed; (4) model predicted no birds present and no birds were observed. The first and the last outcomes are measures of model success, the middle 2 of model failure. A non-parametric bootstrap of the classification comparison was carried out, whereby one-fourth of the predicted and observed comparisons were selected at random with replacement, generating 1000 bootstrap samples of percentages of the 4 possible outcomes.

\section{RESULTS}

Our results illustrate the existence of different types of pelagic habitats in the ETP. For instance, the east- 

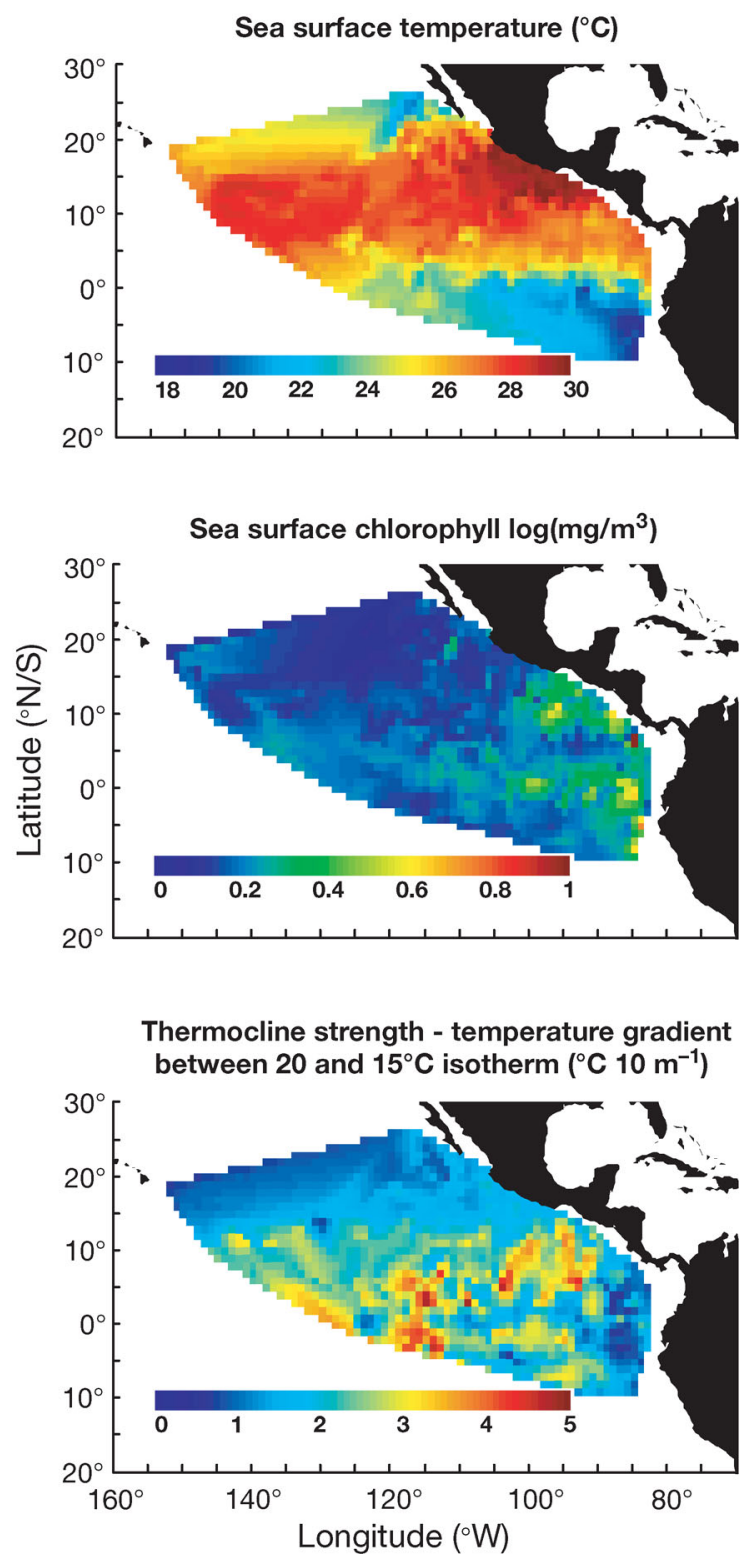

ern shoaling of the thermocline and the meridional temperature gradients created by the equatorial and countercurrent thermocline ridges are visible in the surface plots of the $20^{\circ} \mathrm{C}$ isotherm depth and sea surface temperature (Fig. 2). Shallow $(<30 \mathrm{~m})$ thermoclines and low water column stratification (vertical temperature gradient $<2^{\circ} \mathrm{C} \mathrm{m}^{-1}$ ) are also indicative of upwelling in the gulf of Tehuantepec, Costa Rica Dome and the equatorial cold tongue. As a result, higher surface chlorophyll content is also seen in these same regions (Fig. 2). Furthermore, surface current boundaries and water masses are apparent in the sea surface temperature and salinity surface plots. In general, waters east of $110^{\circ} \mathrm{W}$ and north of the Equatorial Front $\left(\sim 2^{\circ} \mathrm{N}\right)$ were characterized by warm, low

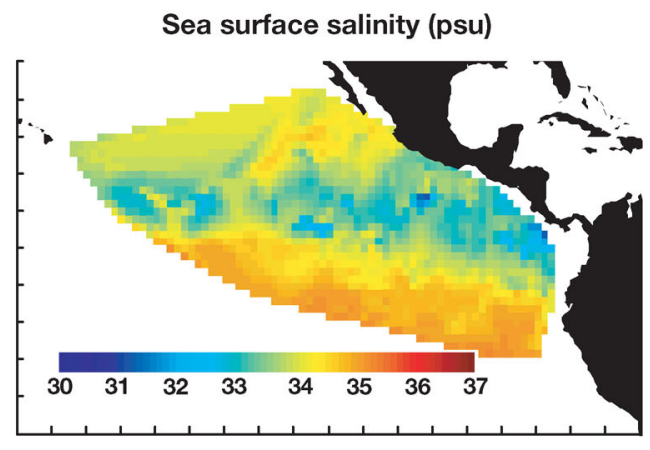

Thermocline depth $-20^{\circ} \mathrm{C}$ isotherm $(\mathrm{m})$

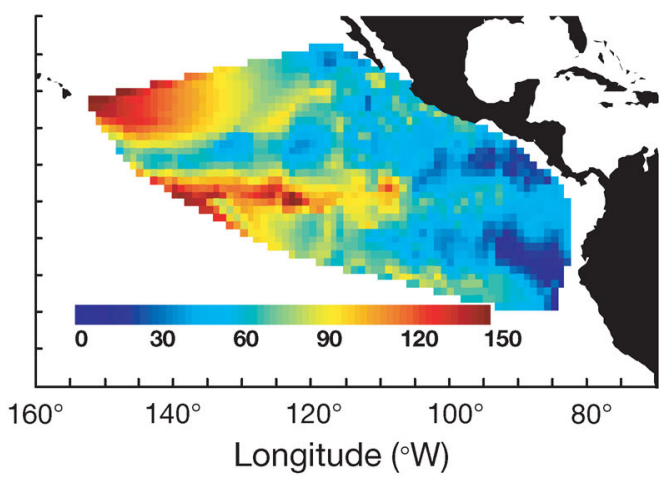

Fig. 2. The 5 environmental variables used to describe oceanographic habitat. Surfaces for plots were created using both 1989 and 1990 survey years. For each oceanographic parameter, grids of spatial data points were interpolated using triangle-based cubic methods based on Delaunay triangulation of the data salinity tropical surface water over a relatively deep thermocline, with the countercurrent thermocline ridge along $10^{\circ} \mathrm{N}$. South of the Equatorial Front, surface waters were cool and saline over a relatively shallow thermocline. The stratification of the water column varied within our study area, showing the following pattern: less water column stratification was seen east of $90^{\circ} \mathrm{W}$, in the areas surrounding the Galápagos Islands, and along the equatorial cold tongue. Also evident in our study area were species-specific distribution patterns (Fig. 3). Of the 6 target species, Juan Fernandez petrel was the most abundant, Leach's storm petrel was the most commonly sighted, and red-tailed tropicbird was the least abundant and least commonly sighted (Table 2). 

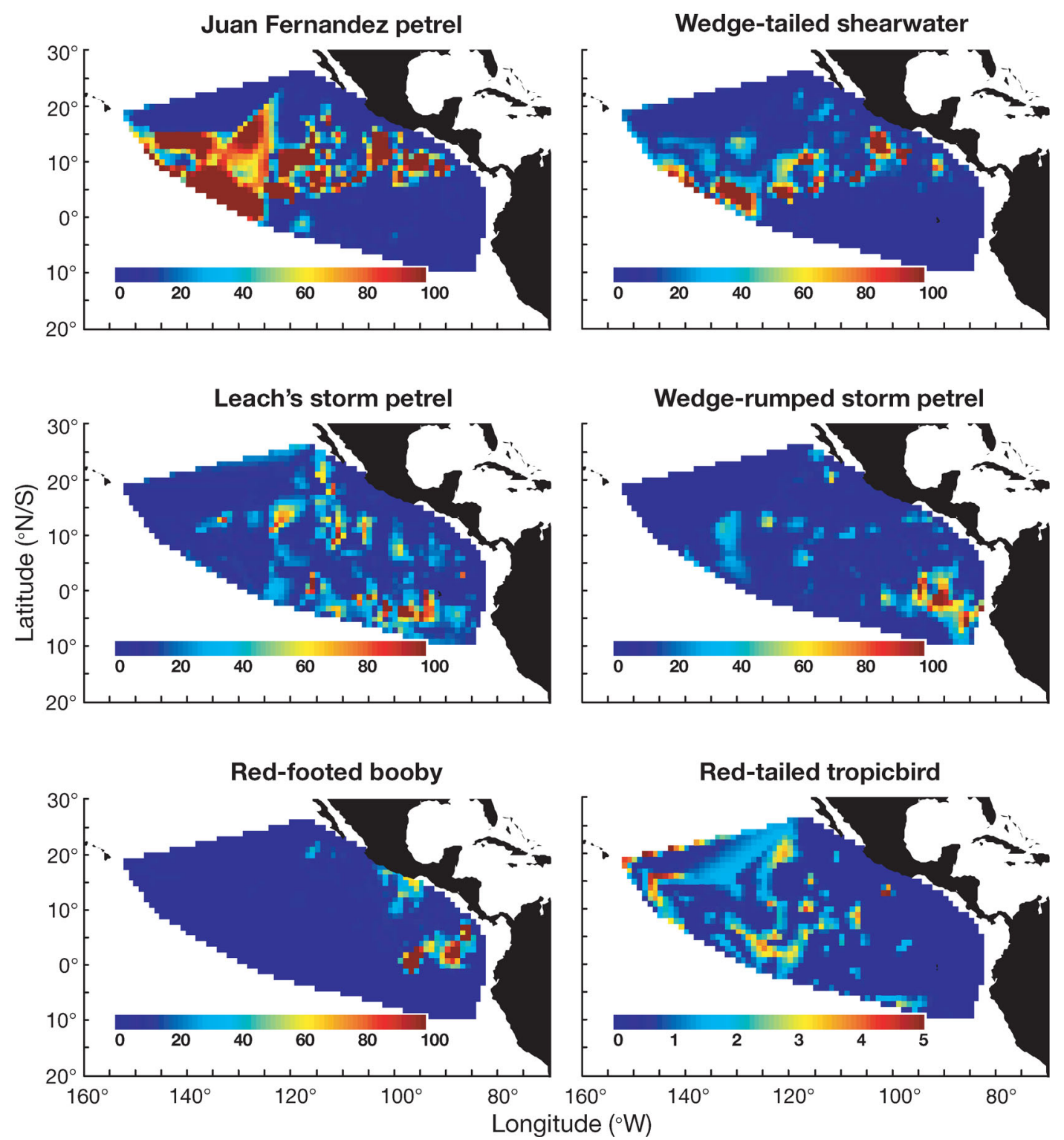

Fig. 3. Surface plots of seabird density (birds $100 \mathrm{~km}^{-2}$ ) using data from both 1989 and 1990 survey years combined. Spatial data gridded as in Fig. 2. Specific names in Table 2

Table 2. Seabird sightings and densities in 1989 and 1990. Density: mean \pm SE birds $100 \mathrm{~km}^{-2}$

\begin{tabular}{|c|c|c|c|c|c|c|}
\hline \multirow[t]{2}{*}{ Species } & \multicolumn{3}{|c|}{1989} & \multirow[b]{2}{*}{$\begin{array}{l}\text { No. } \\
\text { ind. }\end{array}$} & \multirow{2}{*}{$\begin{array}{l}1990 \\
\% \text { days } \\
\text { sighted }\end{array}$} & \multirow[b]{2}{*}{ Density } \\
\hline & $\begin{array}{l}\text { No. } \\
\text { ind. }\end{array}$ & $\begin{array}{l}\% \text { days } \\
\text { sighted }\end{array}$ & Density & & & \\
\hline Juan Fernandez petrel Petroderma externa & 2897 & 41 & $32.31 \pm 6.28$ & 3563 & 55 & $32.82 \pm 6.59$ \\
\hline Wedge-tailed shearwater Puffinus pacificus & 1216 & 50 & $14.32 \pm 2.44$ & 1374 & 56 & $15.90 \pm 3.65$ \\
\hline Leach's storm petrel Oceanodroma leucorhoa & 1873 & 66 & $18.01 \pm 2.61$ & 1611 & 74 & $15.38 \pm 1.60$ \\
\hline Wedge-rumped storm petrel Oceanodroma tethys & 1597 & 66 & $12.64 \pm 1.64$ & 818 & 66 & $8.76 \pm 1.35$ \\
\hline Red-footed booby Sula sula & 650 & 39 & $9.31 \pm 1.85$ & 808 & 25 & $8.82 \pm 4.05$ \\
\hline Red-tailed tropicbird Phaeton rubricauda & 40 & 15 & $0.45 \pm 0.09$ & 34 & 14 & $0.29 \pm 0.06$ \\
\hline
\end{tabular}




\section{Seabird habitat relationships}

The number of significant habitat variables for each seabird species ranged from 3 for the Juan Fernandez petrel, wedge-rumped storm petrel and red-tailed tropicbird, to 5 for red-footed boobies (Table 3). Thermocline depth was common to habitat models for all 6 seabird species. Juan Fernandez petrels, Leach's storm petrels, and red-footed boobies all showed a strong non-linear dependence on significant habitat features, while the other 3 species showed a combination of both linear and non-linear relationships (Fig. 4). Note that these relationships depict only the additional contribution of 1 particular covariate to the model; the effect of each covariate on seabird density is conditional on the others being included in the model. Interpretation of these relationships can only proceed by taking into account the effects of all covariates included.

Habitat preference is based on the interpretation of all curves included in the habitat model. For example, the Juan Fernandez petrel preferred waters with sea surface temperatures and salinities near $28^{\circ} \mathrm{C}$ and $35 \mathrm{psu}$, respectively, and deep (>100 m) thermoclines. The wedge-tailed shearwater also preferred habitats with surface waters near $28^{\circ} \mathrm{C}$ and deep $(>100 \mathrm{~m})$ thermoclines, but also with low surface chlorophyll $\left(<0.2 \log \mathrm{mg} \mathrm{m}^{-3}\right)$, and strong $\left(>2^{\circ} \mathrm{C}^{10} \mathrm{~m}^{-1}\right)$ thermoclines. The 2 storm petrels preferred different oceanic habitat from that used by the Juan Fernandez petrel and wedge-tailed shearwater. Leach's storm petrels preferred surface waters with SSTs near $22^{\circ} \mathrm{C}$, low surface chlorophyll and shallower thermoclines with strong gradients near $3^{\circ} \mathrm{C} 10 \mathrm{~m}^{-1}$. On the other hand, wedge-rumped storm petrels preferred surface waters with higher salinities, higher chlorophyll, and shallow thermoclines that at times breached the surface. Redfooted boobies preferred warm surface waters $\left(>24^{\circ} \mathrm{C}\right)$ with surface salinities and chlorophyll values near $33 \mathrm{psu}$ and $0.4 \mathrm{mg} \mathrm{m}^{-3}$, respectively. Lastly, red-tailed tropicbirds selected surface waters with low chlorophyll $\left(<0.2 \log \mathrm{mg} \mathrm{m}^{-3}\right), 50 \mathrm{~m}$ deep thermoclines, and a wide range of thermocline strengths $\left(1\right.$ to $\left.3^{\circ} \mathrm{C} 10 \mathrm{~m}^{-1}\right)$.

Fig. 5 shows a temperature-salinity diagram with contours of constant density lines $\sigma\left(\mathrm{kg} \mathrm{m}^{-3}\right)$ at 0 (dbar) pressure, constructed from mean temperature and salinity values at each noon position of the survey. Superimposed on the diagram are temperature and salinity combinations of noon positions where more than 10 Juan Fernandez petrels, wedge-tailed shearwaters, Leach's storm petrels and wedge-rumped storm petrels were recorded on that survey day. Distinctions in water mass utilization are clearly discernable between piscivorous and planktivorous seabirds.

Table 3. Environmental variables selected as significant in explaining seabird density (1989) for 6 species, showing for each variable, degrees of freedom (df), F-values for non-parametric effects, and percent reduction in deviance for full model, $\operatorname{Pr}(F)$. Smoothed terms are shown in parentheses; number following each covariable indicates df of smoothing. SST: sea surface temperature; SSS sea surface salinity; $z_{20}$ : depth of $20^{\circ} \mathrm{C}$ isotherm; $z_{\mathrm{DIF}}$ : vertical temperature gradient between 20 and $15^{\circ} \mathrm{C}$ isotherms; Chl: sea surface chlorophyll

\begin{tabular}{|c|c|c|c|c|c|c|}
\hline \multirow{2}{*}{ Species } & \multirow{2}{*}{ Covariables } & \multirow[t]{2}{*}{$\mathrm{df}$} & \multicolumn{3}{|c|}{ Non-parametric } & \multirow{2}{*}{$\begin{array}{l}\text { Reduction in } \\
\text { deviance }(\%)\end{array}$} \\
\hline & & & $\mathrm{df}$ & $F$ & $\operatorname{Pr}(F)$ & \\
\hline \multirow{3}{*}{$\begin{array}{l}\text { Juan Fernandez petrel } \\
\text { Petroderma externa }\end{array}$} & $\mathrm{s}(\mathrm{SST}, 4)$ & 1 & 2.9 & 25.135 & $2.00 \mathrm{E}-13$ & \multirow[t]{3}{*}{73.5} \\
\hline & $\mathrm{s}(\mathrm{SSS}, 4)$ & 1 & 2.9 & 12.114 & $3.64 \mathrm{E}-07$ & \\
\hline & $\mathrm{s}\left(z_{20}, 4\right)$ & 1 & 3 & 17.415 & $6.44 \mathrm{E}-10$ & \\
\hline \multirow{4}{*}{$\begin{array}{l}\text { Wedge-tailed shearwater } \\
\text { Puffinus pacificus }\end{array}$} & $\mathrm{s}(\mathrm{SST}, 4)$ & 1 & 3 & 20.535 & $1.76 \mathrm{E}-11$ & \multirow[t]{4}{*}{67.0} \\
\hline & $\log \mathrm{Chl}$ & 1 & & & & \\
\hline & $z_{20}$ & 1 & & & & \\
\hline & $z_{\mathrm{DIF}}$ & 1 & & & & \\
\hline \multirow{4}{*}{$\begin{array}{l}\text { Leach's storm petrel } \\
\text { Oceanodroma leucorhoa }\end{array}$} & $\mathrm{s}(\mathrm{SST}, 4)$ & 1 & 3 & 10.352 & 0.000 & \multirow[t]{4}{*}{47.9} \\
\hline & $\mathrm{s}(\log C h l, 2)$ & 1 & 0.9 & 5.262 & 0.025 & \\
\hline & $z_{20}$ & 1 & & & & \\
\hline & $\mathrm{s}\left(Z_{\mathrm{DIF}}, 3\right)$ & 1 & 2 & 4.832 & 0.009 & \\
\hline \multirow{3}{*}{$\begin{array}{l}\text { Wedge-rumped storm petrel } \\
\text { Oceanodroma tethys }\end{array}$} & SSS & 1 & & & & \multirow[t]{3}{*}{47.4} \\
\hline & $\mathrm{s}(\log \mathrm{Chl}, 2)$ & 1 & 1 & 5.974 & 0.016 & \\
\hline & $\mathrm{s}\left(z_{20}, 4\right)$ & 1 & 2.8 & 8.686 & 0.000 & \\
\hline \multirow{5}{*}{$\begin{array}{l}\text { Red-footed booby } \\
\text { Sula sula }\end{array}$} & $\mathrm{s}(\mathrm{SST}, 3)$ & 1 & 1.9 & 6.656 & 0.002 & \multirow[t]{5}{*}{62.2} \\
\hline & $\mathrm{s}(\mathrm{SSS}, 3)$ & 1 & 2 & 11.528 & 0.000 & \\
\hline & $\mathrm{s}(\log \mathrm{Chl}, 3)$ & 1 & 1.9 & 6.908 & 0.002 & \\
\hline & $\mathrm{s}\left(z_{20}, 3\right)$ & 1 & 2 & 5.159 & 0.007 & \\
\hline & $\mathrm{s}\left(z_{\mathrm{DIF}}, 2\right)$ & 1 & 1 & 4.885 & 0.029 & \\
\hline \multirow{3}{*}{$\begin{array}{l}\text { Red-tailed tropicbird } \\
\text { Phaeton rubricauda }\end{array}$} & $\log$ Chl 1 & & & & & \multirow[t]{3}{*}{42.8} \\
\hline & $\mathrm{s}\left(z_{20}, 4\right)$ & 1 & 3 & 4.582 & 0.004 & \\
\hline & $\mathrm{s}\left(Z_{\mathrm{DIF}}, 4\right)$ & 1 & 2.9 & 3.867 & 0.011 & \\
\hline
\end{tabular}




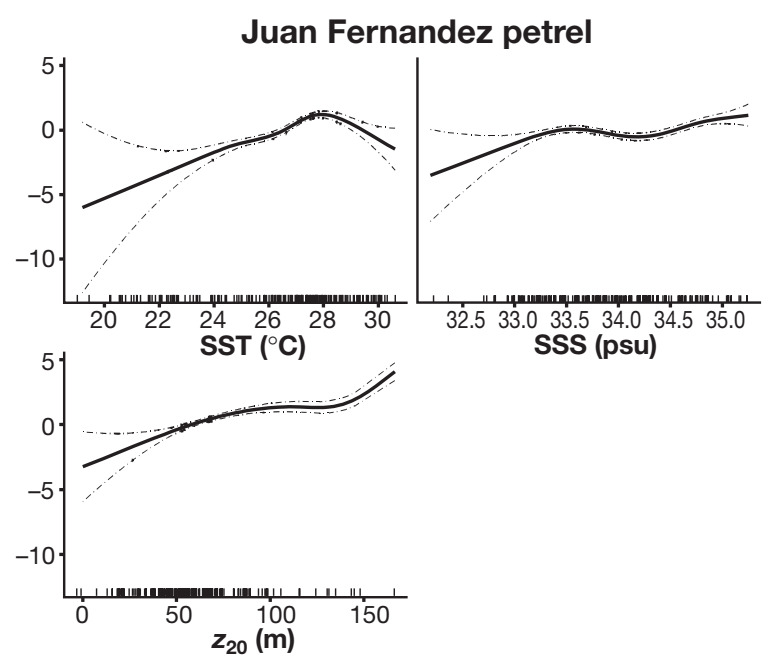

Leach's storm petrel
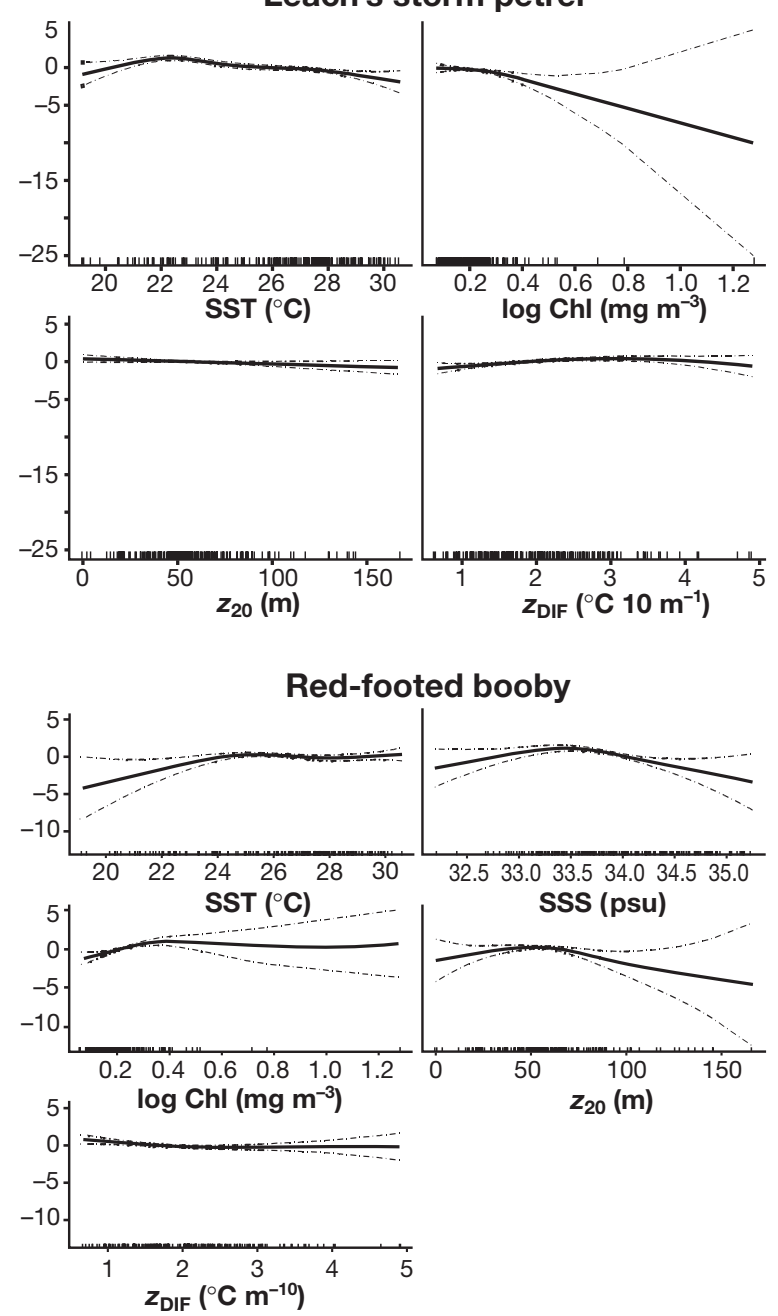
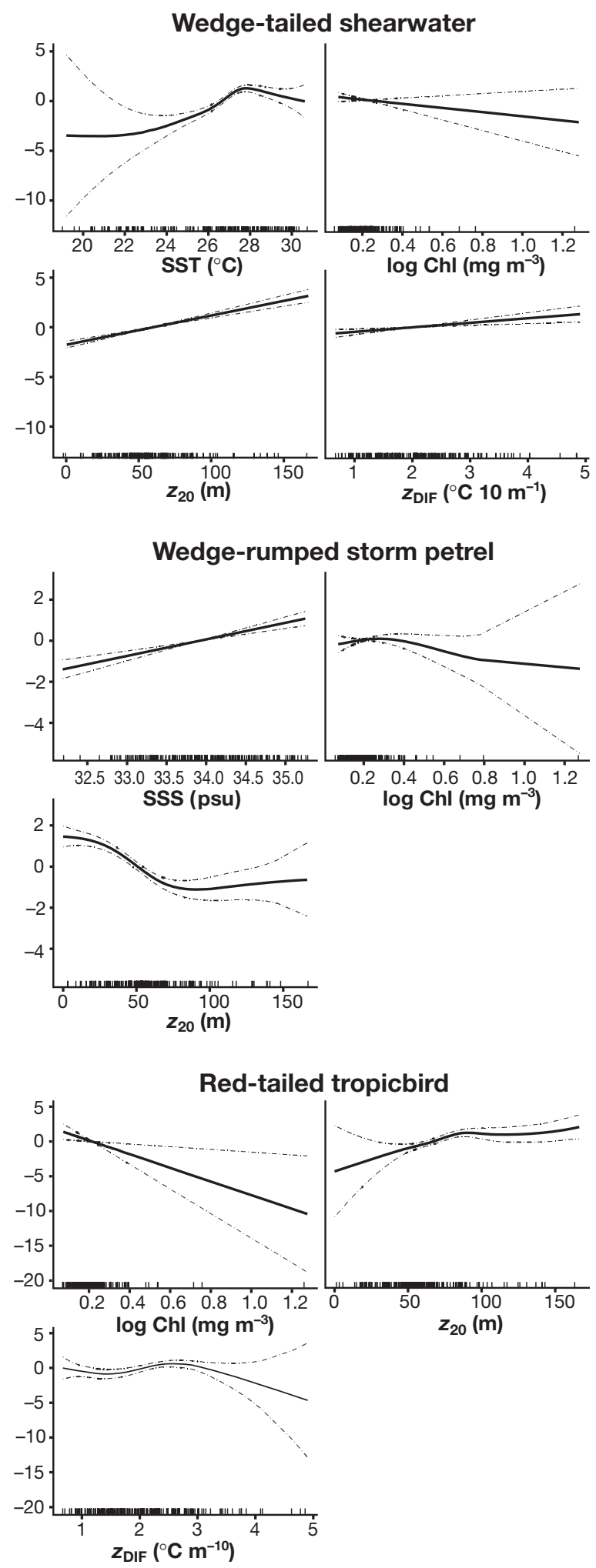

Fig. 4. Generalized additive model (GAM) fit for each seabird species, showing fitted relationships and conditional additive effects of significant oceanographic habitat parameters on density of each seabird species (1989 data only). Dashed lines: upper and lower pointwise twice-standard-error curves; zero on vertical axis corresponds to no effect of relevant explanatory variable on bird density; ticks along the horizontal axis: locations of each survey day relative to relevant oceanographic variable. For specific names see Table 2; for covariables see Table 3 


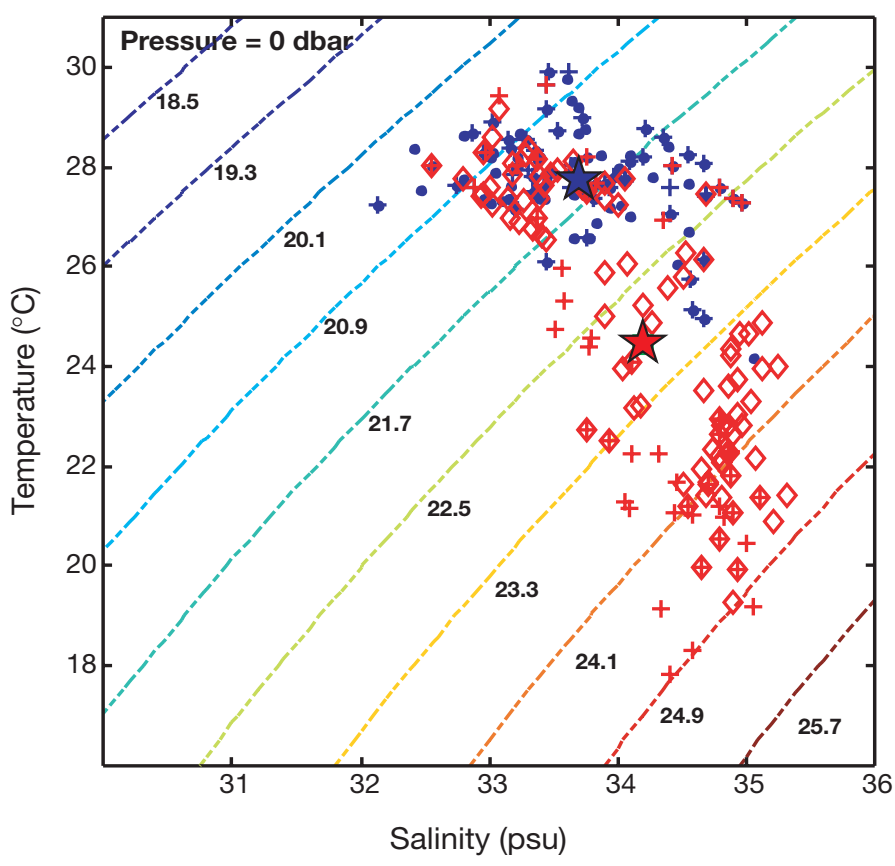

Fig. 5. Temperature-salinity diagram with contours of constant density lines $\sigma\left(\mathrm{kg} \mathrm{m}^{-3}\right)$ at 0 (dbar) pressure. Combination of temperature and salinity of noon positions where Juan Fernandez petrels $(\bullet)$, wedge-tailed shearwaters (+), Leach's storm petrels $(\diamond)$ and wedge-rumped storm petrels $(+)$ were present. Blue indicates piscivorous and red indicates planktivorous feeding guilds. Stars: mean $( \pm \mathrm{SD})$ temperature and salinity for both piscivorous species combined $(\star: 27.77 \pm$ $0.95^{\circ} \mathrm{C}, 33.69 \pm 0.70 \mathrm{psu}$ ) and both planktivorous species combined ( $\star: 24.43 \pm 2.94^{\circ} \mathrm{C}, 34.19 \pm 0.72 \mathrm{psu}$ ). For specific names see Table 2

\section{Model validation}

Models based on 1989 data generally performed well in describing the variability of seabird density distributions, with the reduction of deviance (Table 3) ranging from 73.5 (Juan Fernandez petrel) to $42.8 \%$ (red-tailed tropicbird). The non-parametric bootstrap of the stepwise selection algorithm confirmed the validity of these estimates; however, it also illustrated that a decrease in species abundance increased the degree of uncertainty in the reduction of deviance estimate (Fig. 6). This is clearly seen with the redtailed tropicbird, which had the lowest abundance, lowest reduction of deviance estimate, and consequently the highest bootstrap estimate of standard error and coefficient of variation. Results of the 4-way comparison bootstrap are shown in Fig. 7. The habitat model for the wedge-tailed shearwater had the highest predictive success, with the combined mean percentages of successful outcomes (1 and 4) being $80.5 \%$, whereas the lowest success was for the redfooted booby with $56.6 \%$. In general, habitat models performed well in predicting density distribution patterns, tending to overestimate rather underestimate density (Fig. 7).

\section{DISCUSSION}

Our results suggest that habitat preferences of different foraging guilds are structured around distinct oceanographic features. Of the subsurface predatordependent seabirds, 2 (Juan Fernandez petrels and wedge-tailed shearwaters) preferred oceanic habitat integrated by the tropical surface water mass included in the NECC. The 2 storm petrels were associated with the equatorial surface water mass included in the SEC. Oceanic habitat, however, is comprised of more environmental variables than those distinguishing water masses. Thus, additional habitat parameters should be environmental variables which serve as proxies for prey availability. For example, subsurface predators driving prey to the surface and divergence and/or convergence zones creating either upwelling or downwelling areas with higher productivity and/or aggregates of prey (Ballance \& Pitman 1999, Ballance et al. 2001, Spear et al. 2001). It is also possible to include habitat variables that are not appropriate habitat parameters. This seemed to be the case with red-tailed tropicbirds which are generalists and consequently do not have strong associations with any particular habitat type. This is a likely reason for the poor fit of the red-tailed tropicbird habitat model, since this species feeds solitarily, presumably opportunistically, and has a wide ranging distribution within the ETP (Gould et al. 1974, Pitman 1986, Ballance \& Pitman 1999, Ballance et al. 2001).

Seabird habitat relationships are presumably mostly a function of prey availability; however, breeding location also factors in the selection of seabird habitat. Breeding seabirds are central-place foragers and are thus restricted to searching for prey near island colonies. Conversely, non-breeding seabirds are not restricted to their breeding locations and can venture into oceanic habitat different than that surrounding their colonies. Therefore, oceanographic characteristics of waters surrounding seabird colonies may have little to do with seabird preferential foraging habitat. This seabird trait was apparent in red-footed boobies which, along with Juan Fernandez petrels and wedge-tailed shearwaters, are within the subsurface predator-dependent foraging guild, but did not share the same distributional patterns with these 2 species. Preferred habitat for the red-footed booby included all habitat variables that were part of our study, having only warm SST in common with Juan Fernandez petrels and wedge-tailed shearwaters. Unlike wedge-tailed shearwaters and Juan Fernandez petrels, red-footed boobies 

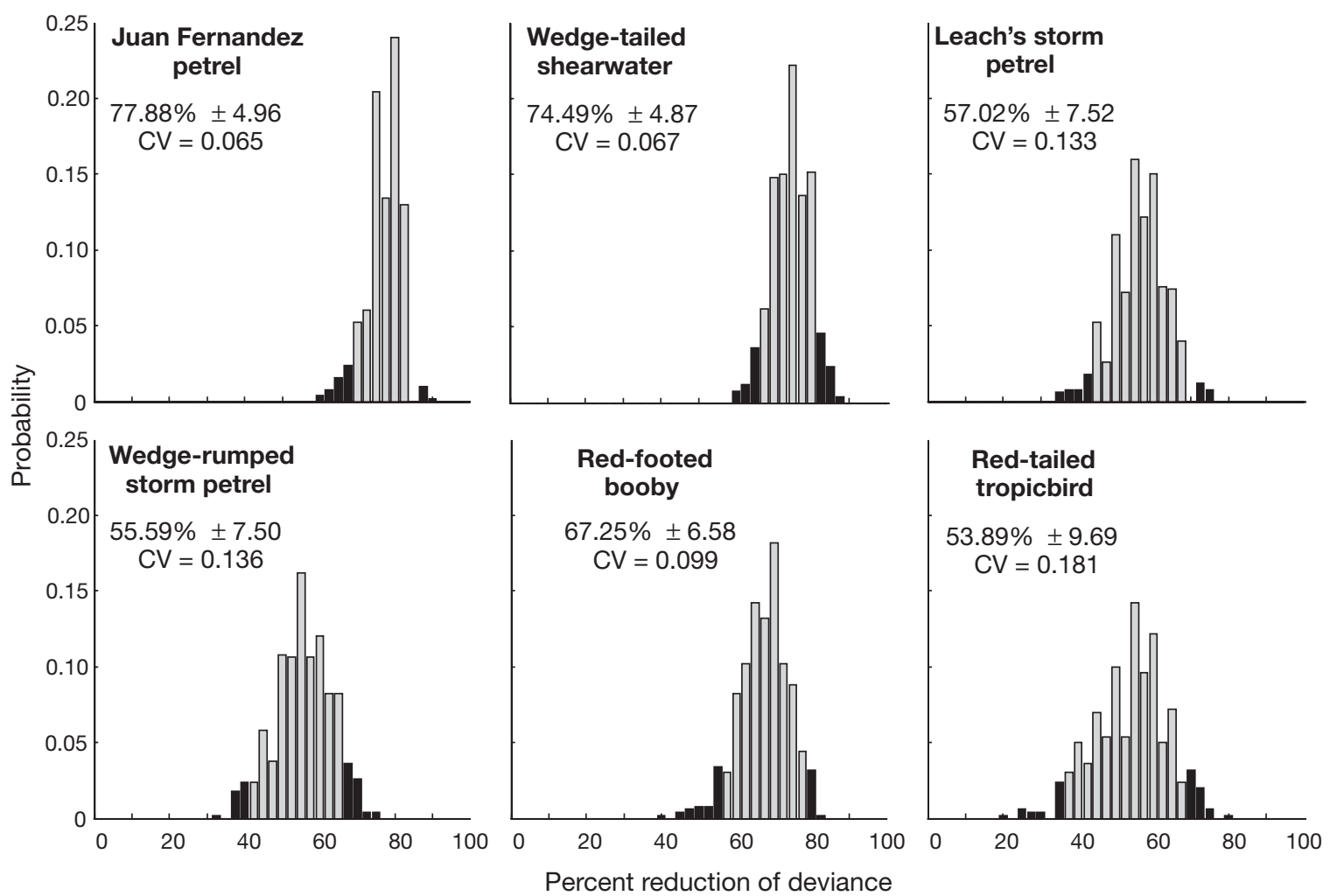

Fig. 6. Results of non-parametric bootstrap evaluating uncertainty of reduction of deviance estimates and showing probability density functions for each of the 500 bootstrap samples for each species. Black bars: $95 \%$ confidence intervals. Mean reduction of deviance ( \pm bootstrap estimate of SE) and coefficient of variation (CV) are shown inside each graph. For specific names see Table 2

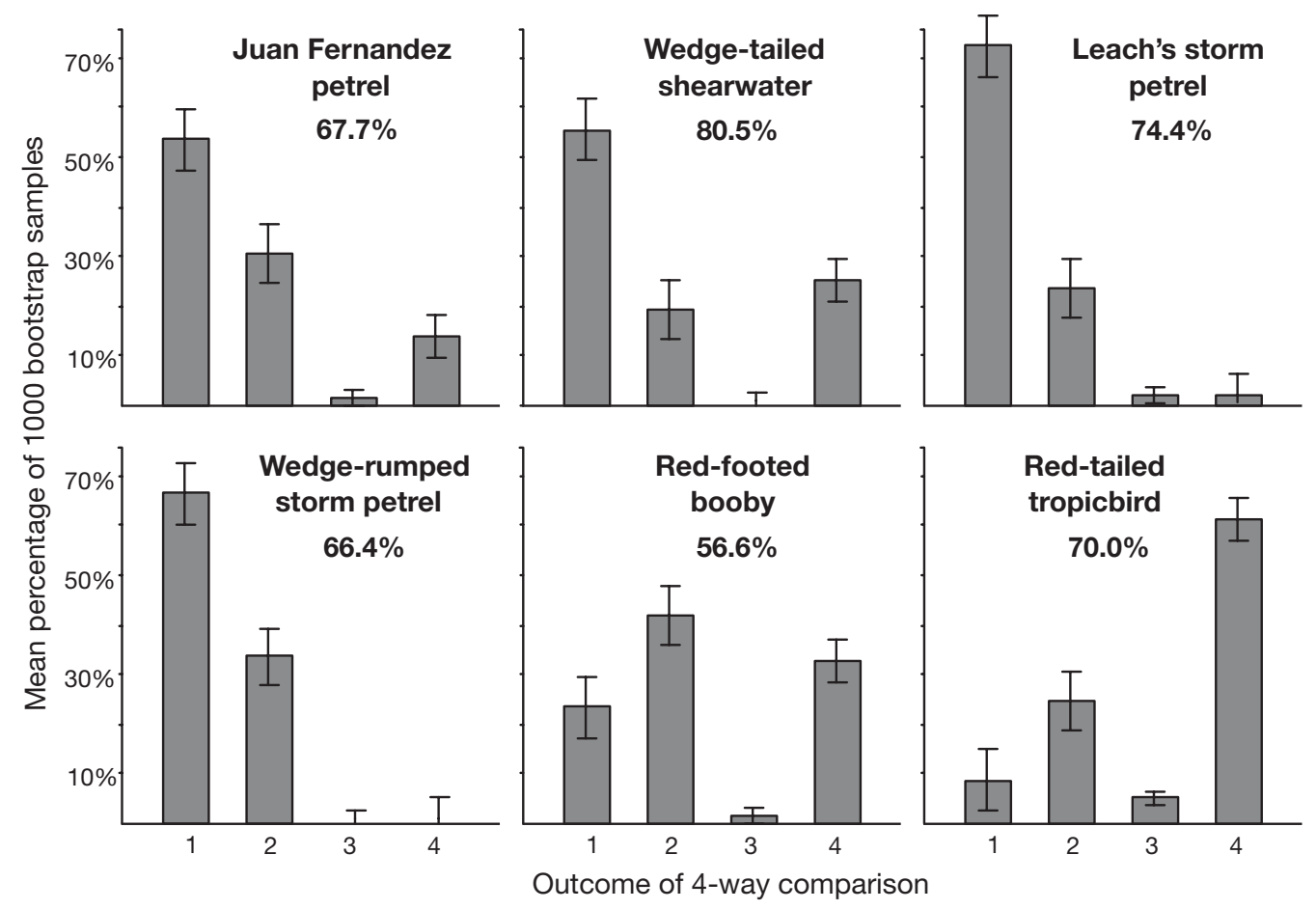

Fig. 7. Results of non-parametric bootstrap of 4-way classification comparison evaluating model success. Bar graphs: mean percent of $1000( \pm \mathrm{SD})$ bootstrap samples of each comparison outcome. Outcomes 1 and 4 indicate model success; see 'Materials and methods' for details, combined percentages of these 2 outcomes are shown inside each graph. For specific names see Table 2 
breed in colonies within the ETP (e.g. Galápagos and Cocos Islands) and rarely forage west of Clipperton Island (Pitman 1986). Juan Fernandez petrels breed on islands off Chile, and wedge-tailed shearwaters breed on Central and South Pacific islands. As a result, Juan Fernandez petrels and wedge-tailed shearwaters foraging in the ETP are non-breeders (either sub-adults or adults between breeding seasons), whereas red-footed boobies include both breeders and non-breeders. In consequence, their distribution patterns are complicated by the fact that the birds are tied to an island and do not reflect preferential foraging habitat.

\section{Water column thermal structure}

Thermocline depth played an important role in the habitat preferences of all seabird species. The habitat models for Juan Fernandez petrels and wedge-tailed shearwaters both included SST and $z_{20}$ as significant parameters, predicting high seabird densities at SSTs near $28^{\circ} \mathrm{C}$ and thermoclines deeper than $100 \mathrm{~m}$. Moreover, the wedge-tailed shearwater habitat model predicted highest densities in areas with sharp temperature gradients or a well-stratified water column. Sharing this type of oceanic habitat are spotted and spinner dolphins, and yellowfin tuna (Au \& Perryman 1985, Reilly 1990, Reilly \& Fiedler 1994). Au \& Perryman (1985) hypothesized that the horizontal barrier created by the strong and deep thermocline creates favorable foraging conditions for tunas and dolphins. Our results confirm this hypothesis, since among our suite of 6 seabird species, Juan Fernandez petrels and wedge-tailed shearwaters associate with tunas and dolphins for feeding opportunities (Au \& Pitman 1986, Ballance et al. 1997). In addition, previous studies have confirmed similar habitat affiliations for these 2 species (King 1974, Ribic \& Ainley 1997, Ribic et al. 1997b).

Water column stratification was also significant for the habitat preferences of the 2 storm petrels. Habitat models for the planktivorous seabirds predicted highest densities in cool $\left(<25^{\circ} \mathrm{C}\right)$ surface waters with much shallower thermoclines $(<30 \mathrm{~m})$. This is directly opposite to the habitat relationships of subsurface predator-dependent seabirds. In particular, the habitat model for the wedgerumped storm petrel predicted highest densities in areas where the $20^{\circ} \mathrm{C}$ isotherm neared the surface, a characteristic typical of the equatorial cold tongue region.

\section{Productivity}

Surface chlorophyll content, when combined with other oceanographic features, such as SST and thermocline depth and strength, can be used to estimate patterns of primary productivity (Falkowski et al. 1998). Surface water primary productivity, therefore, also played an important role in the habitat preferences of seabirds. Subsurface predator-dependent seabirds generally selected habitat with low surface chlorophyll content. Highest densities of wedge-tailed shearwaters were predicted in areas with low surface chlorophyll content $\left(<0.2 \log \mathrm{mg} \mathrm{m}^{-3}\right)$, and Juan Fernandez petrels in habitat typical of tropical surface waters within the NECC, which has lower productivity than waters north and south of this current (Wyrtki 1967, Fiedler et al. 1991). In contrast, the 2 storm petrels were more abundant in surface waters with a less stratified water column, a characteristic typical of upwelling regions and a good indicator of higher productivity. These results concur with Spear et al. (2001) who suggest that planktivorous seabirds tend to forage in divergence and/or convergence zones where the physical characteristics either create higher productivity or aggregate prey into exploitable patches. Associations of planktivorous seabirds with fronts have been well documented (Schneider 1990); hence, it is reasonable to assume that planktivorous seabirds associate with fronts for foraging opportunities.

\section{Species rarity}

Seabird abundance had a strong influence on the model outcome. Among our suite of 6 seabird species, red-tailed tropicbirds had the fewest sightings, meaning that the habitat model for this species was sensitive to the zero-inflated data. Habitat models revealed a decrease in performance with less abundant and rare species and gained robustness with more abundant and common species. The red-tailed tropicbird had the lowest reduction of deviance estimate and the highest amount of variability in the reduction of deviance estimate. The 4-way classification outcome of the red-tailed tropicbird indicated model success in over two thirds of the bootstrap comparisons. Nevertheless, most of these were predicting zero abundance in areas where no birds were present; a likely product of modeling a rare species.

\section{Oceanic habitat structure}

Clearly there is structure in the oceanic habitat of the ETP, and seabirds respond to it. Subsurface predatordependent seabirds associated with regions characterized by deep thermoclines, and planktivores associated with regions characterized by shallow thermoclines. Fig. 8 is a 3-dimensional representation of the thermocline topography in the ETP. Highest densities of Juan Fernandez petrels and wedge-tailed shear- 


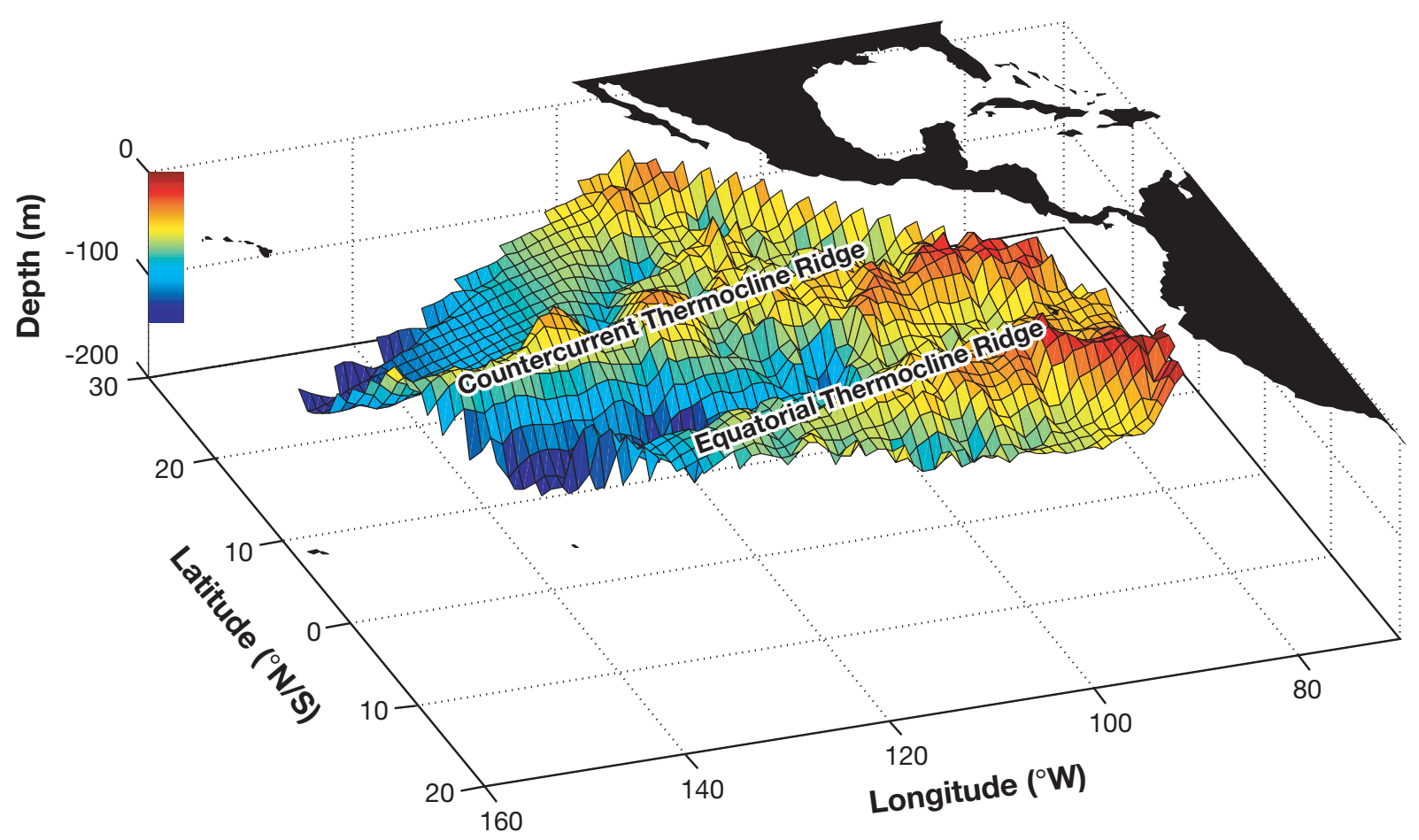

Fig. 8. Three-dimensional representation of thermocline topography. Spatial data gridded as in Fig. 2

waters were observed in the thermocline trough between the countercurrent and equatorial thermocline ridges. Conversely, the highest densities of Leach's and wedge-rumped storm petrels were observed in the 2 thermocline ridges north and south of the thermocline trough. Thermocline depth was a significant feature for all 6 seabird species in our study. We therefore propose that thermocline topography may be a key variable in predicting oceanic habitat of seabirds in the ETP, likely through its effects on the distribution and availability of seabird prey. Future habitat selection studies should aim to include a habitat variable that more directly relates to prey abundance and/or availability.

Acknowledgements. This research could not have been completed without the combined efforts of bird observers and field oceanographers J. Carreta, M. Force, J. Friedrichsen, R. L. Pitman, T. Staudt and V. Andreassi, as well as the officers and crew of the 'David Starr Jordan' and 'McArthur'. Reviews by 3 anonymous reviewers and conversations with J. Forcada, S. Hedley, C. Lennert, M. Landry and L. Scheppke substantially improved earlier drafts of this manuscript.

\section{LITERATURE CITED}

Ainley DG, Boekelheide RJ (1983) An ecological comparison of oceanic seabird communities of the South Pacific Ocean. Stud Avian Biol 8:2-23

Akaike H (1973) Information theory and an extension of the maximum likelihood principle. In: Csàki F, Petrov BN (eds) 2nd International Symposium on Information Theory, Akadèmia Kaido, Budapest, p 267-281

Au DWK, Perryman WL (1985) Dolphin habitats in the eastern tropical Pacific. Fish Bull 86:623-643

Au DWK, Pitman RL (1986) Seabird interactions with dolphins and tuna in the eastern tropical Pacific. Condor 88: $304-317$

Ballance LT, Pitman RL (1999) Foraging ecology of tropical seabirds. In: Adams NJ, Slotow RH (eds) Proceedings of the 22nd International Ornithological Congress, Durban. Bird Life South Africa, Johannnesburg, p 2057-2071

Ballance LT, Pitman RL, Reilly SB (1997) Seabird community structure along a productivity gradient: importance of competition and energetic constraint. Ecology 78: 1502-1518

Ballance LT, Ainley DG, Hunt GL Jr (2001) Seabird foraging ecology. In: Steele JH, Thorpe SA, Turekian KK (eds) Encyclopedia of ocean sciences, Vol 5. Academic Press, London

Ballesteros D, Coen JE (2004) Generation and propagation of anticyclonic rings in the Gulf of Papagayo. Int J Remote Sens 25:2217-2224

Borchers DL, Buckland ST, Priede IG, Ahmadi S (1997) Improving the precision of the daily egg production method using generalized additive models. Can J Fish Aquat Sci 54:2727-2742

Chambers JM, Hastie TJ (1992) Statistical models in S. Wadsworth \& Brooks/Cole Advanced Books \& Software, Pacific Grove, CA

Clarke ED, Spear LB, McCracken ML, Marcques FF, Borchers DL, Buckland ST, Ainley DG (2003) Validating the use of generalized additive models and at-sea surveys to estimate size and temporal trends of seabird populations. J Appl Ecol 40:278-292

Efron B, Tibshirani RJ (1986) Bootstrap methods for standard errors, confidence intervals, and other measures of statistical accuracy. Stat Sci 1:54-77 
Falkowski PG, Barber RT, Smetacek V (1998) Biogeochemical controls and feedbacks on ocean primary production. Science 281:200-206

Fewster RM, Buckland ST, Siriwardena GM, Baillie SR, Wilson JD (2000) Analysis of population trends for farmland birds using generalized additive models. Ecology 81: 1970-1984

Fiedler PC (1992) Seasonal climatologies and variability of eastern tropical Pacific surface waters. Report No. NOAATM-NMFS-SWFC 109, US Department of Commerce, La Jolla, CA

Fiedler PC (2003) The annual cycle and biological effects of the Costa Rica Dome. Deep-Sea Res I 49:321-338

Fiedler PC, Philbrick V, Chavez FP (1991) Oceanic upwelling and productivity in the eastern tropical Pacific. Limnol Oceanogr 36:1834-1850

Forney KA (2000) Environmental models of cetacean abundance: reducing uncertainty in population trends. Conserv Biol 14:1271-1286

Gerrodette T, Wade PR (1991) Monitoring trends in dolphin abundance in the eastern tropical Pacific: analysis of five years of data. Rep Int Whal Comm 41:511-515

Gould PJ, King WB, Sanger GA (1974) Red-tailed tropicbird (Phaethon rubricauda). In: King WB (ed) Pelagic studies of seabirds in the central and eastern Pacific Ocean. Smithson Contrib Zool 158:207-231

Harrison CS, Hida TS, Seki MP (1985) Hawaiian seabird feeding ecology. Wildl Monogr 85:1-71

Hastie TJ, Tibshirani RJ (1999) Generalized additive models. Chapman \& Hall/CRC, London

Hedley SL, Buckland ST, Borchers DL (1999) Spatial modeling from line transect data. J Cetacean Res Manag 1:255-264

Huntington CE, Butler RG, Mauck RA (1996) Leach's storm petrel (Oceanodroma leucorhoa). In: Gill F, Poole A (eds) The birds of North America. Academy of Natural Sciences, Philadelphia, PA, and the American Ornithologists Union, Washington, DC, No. 233

Kessler WS (2002) Mean three-dimensional circulation in the northeast tropical Pacific. J Phys Oceanogr 32:2457-2471

King WB (1974) Wedge-tailed shearwater (Puffinus pacificus). In: King WB (ed) Pelagic studies of seabirds in the central and eastern Pacific Ocean. Smithson Contrib Zool 158: 53-95

Lierhiemer LJ, Fiedler PC, Reilly SB, Pitman RL, Ballance LT, Beavers SC, Berhringer DW (1990a) Report of ecosystem studies conducted during the 1989 eastern tropical Pacific dolphin survey on the research vessel McArthur. Report No. NOAA-TM-NMFS-SWFC 140, US Department of Commerce, La Jolla, CA

Lierhiemer LJ, Fiedler PC, Reilly SB, Pitman RL, Ballance LT, Beavers SC, Thomas CD, Berhringer DW (1990b) Report of ecosystem studies conducted during the 1989 eastern tropical Pacific dolphin survey on the research vessel David Starr Jordan. Report No. NOAA-TM-NMFS-SWFC 139, US Department of Commerce, La Jolla, CA

McCullagh P, Nelder JA (1989) Generalized linear models. Chapman \& Hall, London

McGowan JA (1986) The biogeography of pelagic ecosystems. UNESCO Tech Pap Mar Sci 49:191-200

Owen RW (1981) Fronts and eddies in the sea: mechanisms, interactions, and biological effects. In: Longhurst AR (ed) Analyses of marine ecosystems. Academic Press, London, p $197-233$

Philbrick V, Fiedler PC, Reilly SB, Pitman RL, Ballance LT, Berhringer DW (1991a) Report of ecosystem studies conducted during the 1990 eastern tropical Pacific dolphin survey on the research vessel McArthur. Report No.

Editorial responsibility: Kenneth Sherman (Contributing Editor), Narragansett, Rhode Island, USA
NOAA-TM-NMFS-SWFC 161, US Department of Commerce, La Jolla, CA

Philbrick V, Fiedler PC, Reilly SB, Pitman RL, Ballance LT, Thomas GG, Berhringer DW (1991b) Report of ecosystem studies conducted during the 1990 eastern tropical Pacific dolphin survey on the research vessel David Starr Jordan. Report No. NOAA-TM-NMFS-SWFC 160, US Department of Commerce, La Jolla, CA

Pitman RL (1986) Atlas of seabird distribution and relative abundance in the eastern tropical Pacific. Report No. LJ86-02C, NMFS, Southwest Fisheries Center, La Jolla, CA

Pitman RL, Ballance LT (1990) Daytime feeding by Leach's storm petrel on a midwater fish in the eastern tropical Pacific Ocean. Condor 92:524-527

Pocklington R (1979) An oceanographic interpretation of seabird distributions in the Indian Ocean. Mar Biol 51: 9-21

Reilly SB (1990) Seasonal changes in distribution and habitat differences among dolphins in the eastern tropical Pacific. Mar Ecol Prog Ser 66:1-11

Reilly SB, Fiedler PC (1994) Interannual variability of dolphin habitats in the eastern tropical Pacific. I: Research vessel surveys, 1986-1990. US Natl Mar Fish Serv Fish Bull 92: $434-450$

Ribic CA, Ainley DG (1997) The relationships of seabird assemblages to physical habitat features in Pacific equatorial waters during spring 1984-1991. ICES J Mar Sci 54: 593-599

Ribic CA, Ainley DG, Spear LB (1997a) Scale-related seabirdenvironmental relationships in Pacific equatorial waters, with reference to El Niño-Southern Oscillation events. Mar Ecol Prog Ser 156:183-203

Ribic CA, Ainley DG, Spear LB (1997b) Seabird associations in Pacific equatorial waters. Ibis 139:482-487

Rosenzweig ML (1981) A theory of a habitat selection. Ecology 62:327-355

Schneider DC (1990) Seabirds and fronts: a brief overview. Polar Res 8:17-21

Spear LB, Ainley DG (2005) At-sea distributions and abundance of tropicbirds in the eastern Pacific. Ibis 147: 353-366

Spear LB, Ainley DG, Ballance LT (2001) Responses of seabirds to thermal boundaries in the tropical Pacific: the thermocline versus the Equatorial Front. Mar Ecol Prog Ser 219:275-289

Stoner AW, Manderson JP, Pessutti JP (2001) Spatially explicit analysis of estuarine habitat for juvenile winter flounder: combining generalized additive models and geographic information systems. Mar Ecol Progr Ser 213:253-271

Swartzman G, Silverman E, Williamson N (1995) Relating trends in walleye pollock (Theragra chalcogramma) abundance in the Bering Sea to environmental factors. Can J Fish Aquat Sci 52:369-380

Tasker ML, Jones PH, Dixon T, Blake BF (1984) Counting seabirds at sea from ships: a review of methods employed and a suggestion for a standardized approach. Auk 101: 567-577

Wade PR, Gerrodette T (1992) Estimates of dolphin abundance in the eastern tropical Pacific: preliminary analysis of five years of data. Rep Int Whal Comm 42:533-539

Wahl TR, Ainley DG, Benedict AH, Degange AR (1989) Associations between seabirds and water masses in the northern Pacific Ocean in summer. Mar Biol 103:1-12

Wyrtki K (1966) Oceanography of the eastern equatorial Pacific Ocean. Oceanogr Mar Biol Annu Rev 4:33-68

Wyrtki K (1967) Circulation and water masses in the eastern equatorial Pacific Ocean. Int J Oceanol Limnol 1:117-147

Submitted: March 18, 2003; Accepted: September 16, 2005 Proofs received from author(s): May 22, 2006 